\title{
Study on The Fire Cracks of Slabbing Mill Rolls*
}

\author{
By Chiyuki Utahashi, ${ }^{* *}$ Takayoshi Yanagisawa, ${ }^{* *}$ Mikio Hachisu, ${ }^{* * *}$ Takeomi Okumoto,**** \\ Eisuke Niiyama, ${ }^{* * *}$ Jurō Watanabe**** and Tsuruo Shibazaki******
}

\section{Synopsis}

A series of experiments were carried out on the effect of rolling variables on fire cracking on the rolls of a universal type slabbing mill.

Types and arrangement of nozzles for roll cooling water were changed in succession and it was established that cooling of roll surface should be done at location as far from the delivery point as possible, in order to minimize fire cracking.

Maximum temperature of roll surface during rolling was determined by measurement of hardness of the steel pieces embedded in roll surface. The surface temperature was approximately $500^{\circ} \mathrm{C}$. Temperature of bottom roll was higher than that of top roll. Depth of heat-affected zone was 2 $\mathrm{mm}$ from surface.

Mode of machining of roll surface had no effect on the occurrence of randomly oriented fire cracks, while they had a definite influence on circumferential cracks. Apparently smooth surface provided by a flat-tipped cutter induced such cracks.

Wear profiles of the rolls were obtained by a micrometer and top roll was found to wear down $35 \%$ more than bottom.

Roll speed was recorded by motion picture and top roll was found to revolve 2 degrees more than the bottom in a pass. This was related to different wear and cracking behaviour of the both rolls.

\section{Introduction}

Because of the recent demand for the increased production rate in a slabbing mill, improved roll life has become more important than ever. Roll life depends on various factors such as resistance to breakage, wear or fire cracking. In the present investigation fire cracking was taken up as the major subject, as it was considered to be related to all the other factors influencing the roll life.

Fire cracks can be seen on all the hot working rolls, wherein slabbing mill rolls are most severely affected by them. It is generally accepted that fire cracking involves thermal fatigue, as the rolls are subjected to repeated heating and cooling during rolling operation. Once they appear on the roll surfaces, they may accelerate roll breakage due to the bending force in rolling. Deep fire cracks necessitate heavy dressing, and thus lead to shorter roll life. At times, fire cracks may cause roll surface spalling.

Despite the extensive investigation carried out up to date in both Japan $^{3), 4)}$ and overseas ${ }^{5), 6)}$, satisfactory prevention of fire cracking has not yet been accomplished. The present investigation was carried out on the universal type slabbing mill of the Chiba Works of Kawasaki Steel Corp. in collaboration by a roll user, Kawasaki and two roll makers, Hitachi, Ltd. and The Japan Steel Works, Ltd.

The study was motivated by an observation made of the horizontal rolls in the mill that the top rolls suffered little fire cracking, while the bottom rolls suffered more or less cracking regardless of the maker or the material of the rolls. The aim of the study was to obtain the bottom roll surfaces with as little fire cracking as the top ones.

The most part of the investigation was performed with the actual rolls used in the mill. Although laboratory experiments were conducted when necessary, the results were regarded only as supplementary. The activity was continued for about a year and the following was the result.

\section{Mill and the Rolls Studied}

The mill concerned with the present investigation had the following specifications.

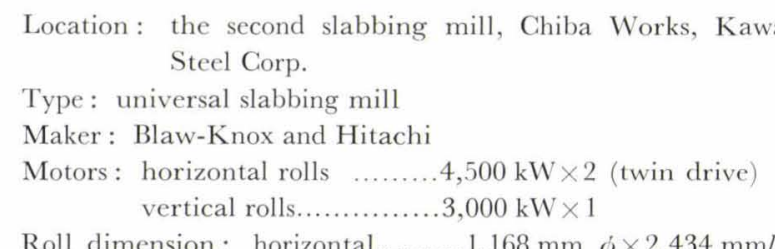

Roll dimension : horizontal........1,168 $\mathrm{mm} \dot{\phi} \times 2,434 \mathrm{~mm} l$

Rolling speed : 0-40-80 rpm

Roll cooling water: pump exit pressure........ $10 \mathrm{~kg} / \mathrm{cm}^{2}$

pump capacity $\ldots \ldots \ldots \ldots \ldots 500 \mathrm{t} / \mathrm{hr}$
flow rate $\ldots \ldots \ldots \ldots \ldots \ldots . .230 \sim 270 \mathrm{t} / \mathrm{hr}$

(incl. vertical rolls)

Products : 8 to 27 tons in weight, 80 to $400 \mathrm{~mm}$ in thickness, 900 to $1,900 \mathrm{~mm}$ in width

Pass number: 7 to 19 passes (for plain carbon steel)

Metal temperature : $1,200^{\circ}$ to $1,250^{\circ} \mathrm{C}$ before rolling

$1,050^{\circ}$ to $1,100^{\circ} \mathrm{C}$ after rolling

Roll material : low alloy cast steel with 0.7 to $1.0 \% \mathrm{C}$, carbide particles being spheroidized by heat treatment

The general view of the stand and the dimensions of the rolls are shown in Fig. 1 and Photo 1 respectively. The themes and the procedures of the experiments are listed in Table 1.

\section{Effect of Roll Cooling on Fire Cracking}

\footnotetext{
* This article is in reference to the lecture delivered before the 66th Grand Lecture Meeting of The Iron \& Steel Institute of Japan held in October 1963 in Nagoya. Japanese text was received on May 15,1964 and printed in Tetsu-to-Hagané (Journal, Iron \& Steel Institute, Japan), 51 (1965), 1, 39-59.

** Kawasaki Steel Corp.

$* * * \quad$ Hitachi, Ltd.

$* * * * \quad$ Dr. Sc., Hitachi, Ltd.

$* * * * * \quad$ Dr. Eng., The Japan Steel Works, Ltd.

$* * * * * * \quad$ The Japan Steel Works, Ltd.
} 


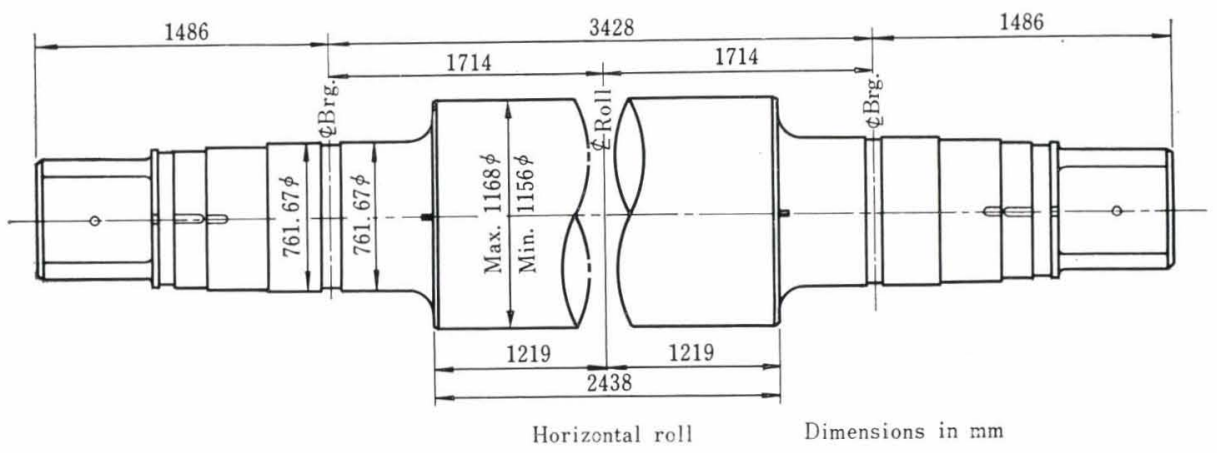

Fig. 1

Roll dimensions

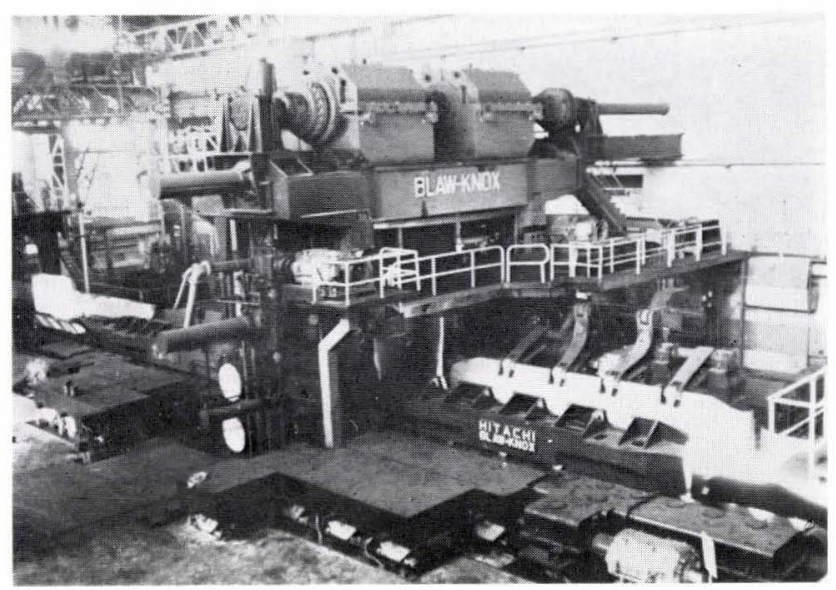

Photo 1. General view of roll stand

Table 1. Subjects and procedures of experiments

Subjects

Procedures

\begin{tabular}{|c|c|c|c|}
\hline \multirow{2}{*}{ (1) } & \multirow{2}{*}{$\begin{array}{l}\text { Roll surface obser- } \\
\text { vation after rolling }\end{array}$} & (a) & Photographing \\
\hline & & (b) & Plaster replica \\
\hline \multirow{3}{*}{ (2) } & \multirow{3}{*}{$\begin{array}{l}\text { Roll surface tem- } \\
\text { perature measure- } \\
\text { ment }\end{array}$} & (a) & Alcohol thermometer \\
\hline & & (b) & Contact thermocouple \\
\hline & & (c) & Plugging technique \\
\hline$(3)$ & $\begin{array}{l}\text { Roll wear } \\
\text { measurement }\end{array}$ & (a) & $\begin{array}{l}\text { Diameter measurement with } \\
\text { micrometer }\end{array}$ \\
\hline (4) & $\begin{array}{l}\text { Fire cracks vs. } \\
\text { pick-up adjustment }\end{array}$ & (a) & $\begin{array}{l}\text { Photographing of roll surfaces with the } \\
\text { change in pick-up height }\end{array}$ \\
\hline \multirow{2}{*}{ (5) } & \multirow{2}{*}{$\begin{array}{l}\text { Fire cracks vs. roll } \\
\text { cooling water }\end{array}$} & (a) & Photographing of spray \\
\hline & & (b) & $\begin{array}{l}\text { Photographing of roll surfaces with the } \\
\text { change in cooling conditions }\end{array}$ \\
\hline (6) & $\begin{array}{l}\text { Tests of water } \\
\text { spray nozzle }\end{array}$ & (a) & $\begin{array}{l}\text { Observation of spray pressure distribu- } \\
\text { tion by silica board test }\end{array}$ \\
\hline (7) & $\begin{array}{l}\text { Fire cracks vs, roll } \\
\text { surface finish }\end{array}$ & (a) & $\begin{array}{l}\text { Photographing of roll surfaces with the } \\
\text { change in machining conditions }\end{array}$ \\
\hline (8) & $\begin{array}{l}\text { Measurement of } \\
\text { roll speed }\end{array}$ & (a) & $\begin{array}{l}\text { Motion ( } 64 \text { frames per second) photo- } \\
\text { graphing of rotating rolls }\end{array}$ \\
\hline
\end{tabular}

As the bottom rolls exhibited more severe fire cracking than the top ones, effort was concentrated on improving the bottom roll cooling system to produce better surfaces. (Table 2)

\section{The First Period}

The original cooling system at the time of construction of the mill is illustrated in Fig. 2, corresponding roll surfaces being reproduced in Photo 2(a). The top rolls were characterized by pronounced worn surfaces, while the bottom ones were characterized by
Table 2. Changes in roll cooling variables

\begin{tabular}{c|c}
\hline Period & \multicolumn{1}{c}{ Changes in roll cooling variables } \\
\hline \multirow{2}{*}{ I } & i) Adjustment of flow rates of both rolls \\
\hline ii) Bottom roll cooling header angle: $30^{\circ}$ upward $\rightarrow 35^{\circ}$ up \\
\hline iii) Bottom roll cooling header angle: $35^{\circ}$ up $\rightarrow 0^{\circ}$
\end{tabular}

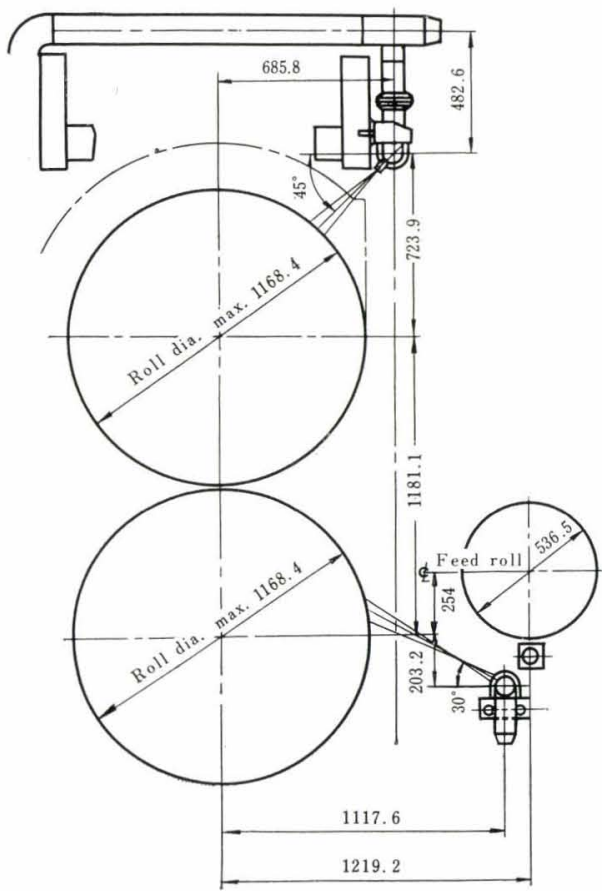

Fig. 2. Original roll cooling arrangement

severe fire cracking.

The probable differences in cooling conditions between the top and the bottom rolls apparent in Fig. 2 were as follows:

(1) The spray nozzles were 1.6 times more distant from the bottom roll surface than from the top ones, 


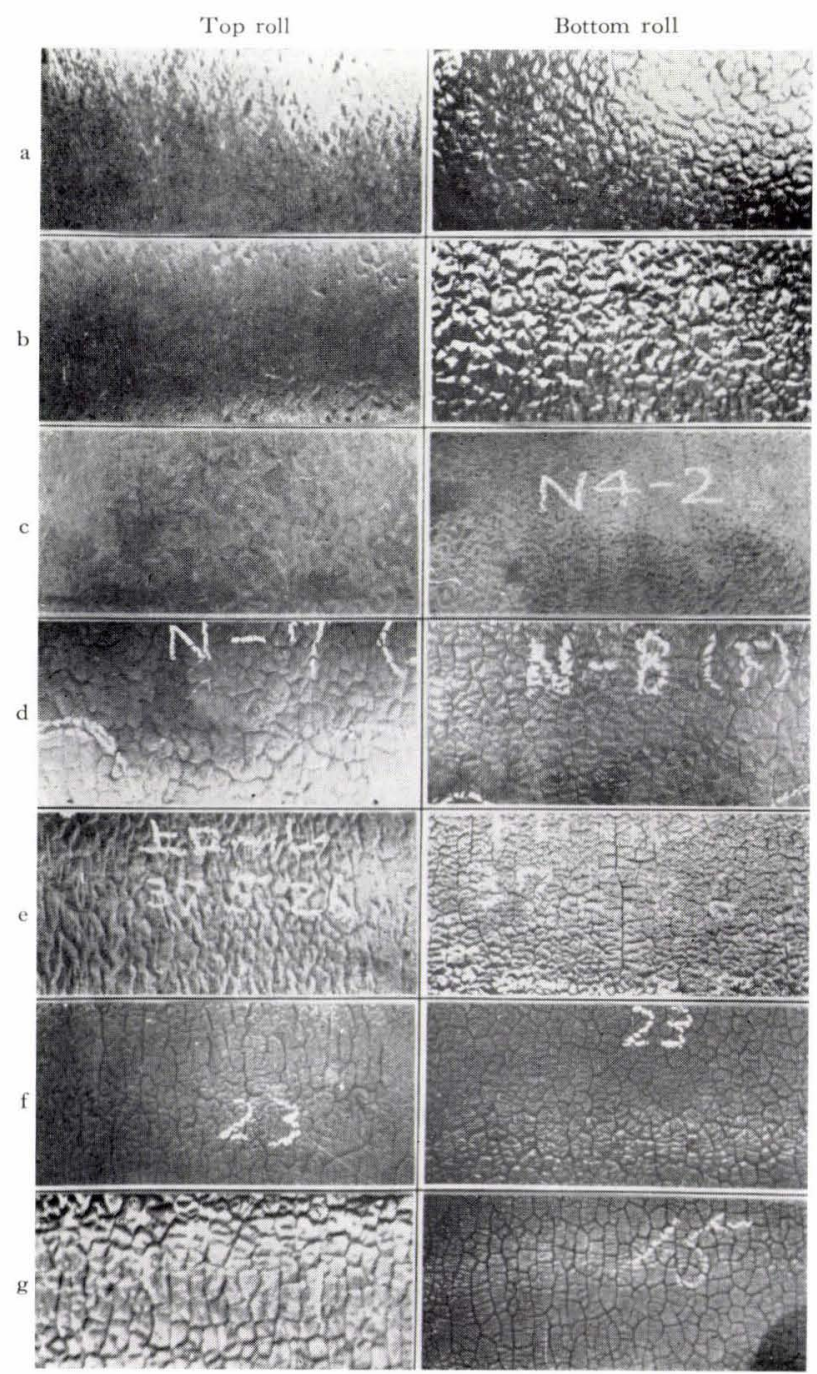

Photo 2. Roll surfaces after rolling with different cooling arrangements

while the type of the nozzles were the same.

(2) A given point on the bottom roll surface was cooled by the spray sooner after delivery of a slab than the corresponding point on the top roll, because of the difference of the relative position of the sprays, thus the temperature of the point before cooling being higher in the former than in the latter.

(3) The top roll was cooled sufficiently by the water pool formed between the wiper and the roll. Furthermore, the excess water flowing down from the pool along the roll barrel toward the delivery point gave the roll a slow preliminary cooling before the final cooling by the pool. Such condition was nonexistent in the case of the bottom roll.

(4) As the nozzles for the bottom rolls were installed 30 degree upward, a part of the water hitted the slab and the splash thus made tended to obstruct the spray itself.

Roll surface temperature after rolling was measured by means of alcohol thermometer. The top roll was from 45 to 48 degree, while the bottom was about 55 degree. The difference in the temperature was considered, at least partly, to be due to the factors cited above.

Several changes were made in the cooling system and the results were assessed from the roll surface appearance. Adjusting the flow rates of the water for the both rolls resulted in little change in the surface. Lowering the nozzle angle for the bottom roll by 5 degrees downward gave slight improvement in the surface, as evidenced by the decreased amount of dressing.

\section{The Second Period}

Spray nozzle angle for the bottom roll was changed to 15 degree downward, in order to start cooling as late as the top roll. The direct result was a slight increase in the roll temperature, due to the decreased total cooling time for one rotation of the bottom roll. A cure was made for this temperature rise by installing a new set of five water pipes of $1^{1 / 4}$ inch in diameter along the bottom roll barrel on the sled, with 20 holes of diameter of $2 \mathrm{~mm}$ for spraying being drilled on each pipe, as illustrated in Fig. 3.

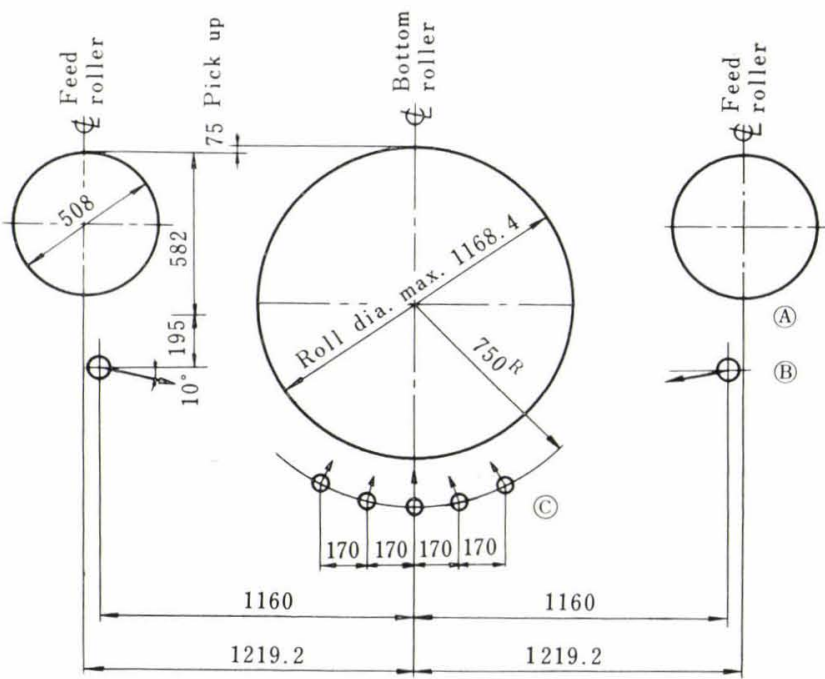

Fig. 3. Roll cooling arrangement in the period II A. (See Photo 2(b))

As a result of these changes in the cooling system, finer fire cracking was observed than before (Photo $2(\mathrm{~b}))$.

A further change was made in the cooling system by installing a new low pressure spray nozzles (3 $\mathrm{kg} / \mathrm{cm}^{2}$ ) directed to a point on bottom roll surface as near the delivery point as possible so that the bottom could be cooled slowly immediately after the delivery of a slab before severe cooling by the main spray nozzle (Fig. 4). After these changes it was observed that the start of cracking was retarded and the unit size of crack cell and the depth of cracks decreased, while a new type of circumferential cracks became apparent on the overall roll surfaces, as reproduced in Photo 2(c), which became a subject of a separate section of the study as will be described later.

\section{The Third Period}

Filler plates were changed so that the height of slab pick-up at the entrance was set at 2 to $2 \frac{1}{2}$ inch $(50$ to $62 \mathrm{~mm}$ ) as compared to 3 inch in the original design. The aim of the change was to decrease the amount of 


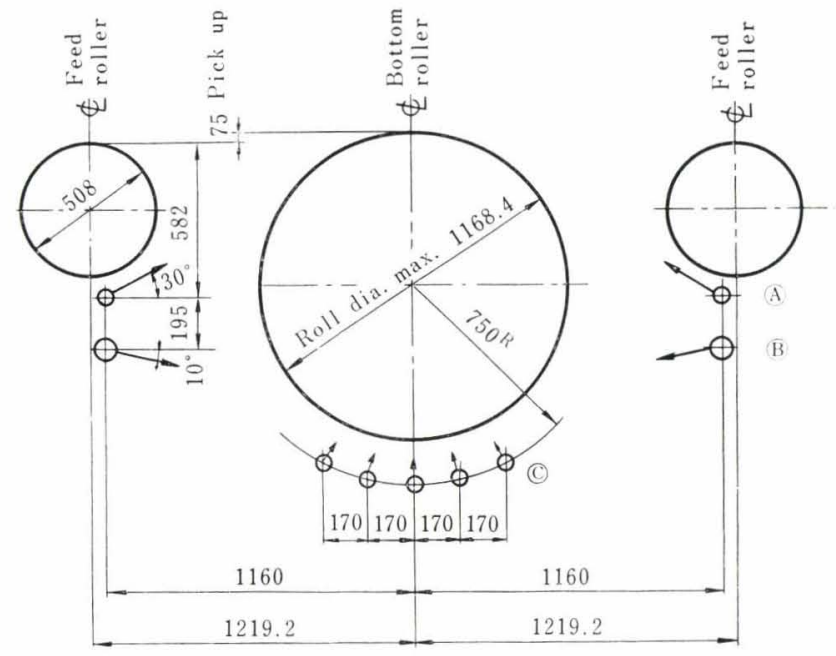

Fig. 4. Roll cooling arrangement in the period II B. (See Photo 2(c))

wear on the top roll so that the difference of the surface appearance on the both rolls would decrease. The result was along with the expectation as indicated in Photo 2(d).

\section{The Fourth Period}

Types of spray nozzles were changed after performing a test on spray pressure distribution. The test consisted of spraying water from the nozzle to be tested against a silica board at a certain distance with a certain pressure and measuring the size of the area on the board depressed by the spray. The results are summarized in Table 3. To show the way of designating a nozzle, let us take an example of 1/2KB5750: $1 / 2$ refers to the diameter of fitting in inch, $\mathrm{KB}$ is the maker's symbol, 57 is the amount of water flow in liter per minute at the pressure of 3 $\mathrm{kg} / \mathrm{cm}^{2}, 50$ is the nominal spray angle in degree. The shapes and dimensions of each nozzle are shown in Photo 3.

The nozzle 1/2KB6520 exhibited a broad and uniform pressure distribution and was chosen to replace five of the original $1 / 2 \mathrm{~KB} 5750$ at the middle of the roll barrel length in both fore and back sides of the rolls. This change resulted in a decreased unit crack cell size and a change in a location of the start of cracking, as reproduced in Photo 2(e).

5. The Fifth Period

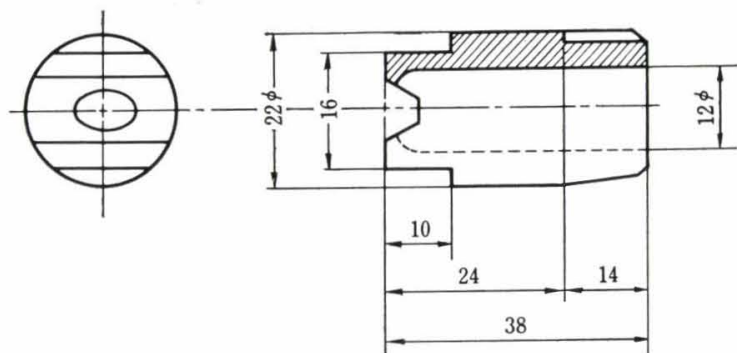

Nozzle No. $1 / 2$ KB5750
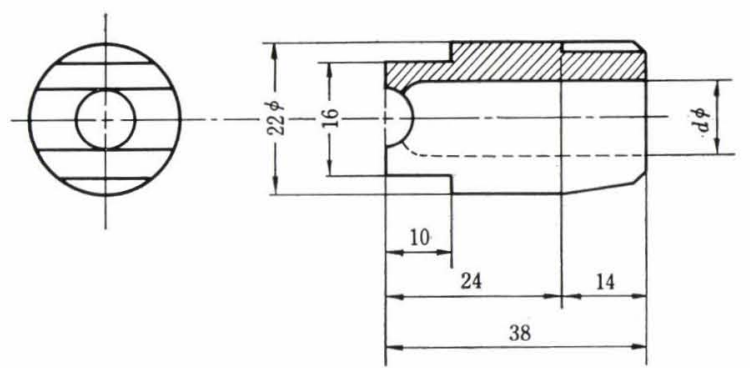

Nozzle No. $1 / 2$ KB5020 $d=9.5$ $1 / 2 \mathrm{~KB} 5520 d=9.5$

$1 / 2 \mathrm{~KB} 6520 d=10$

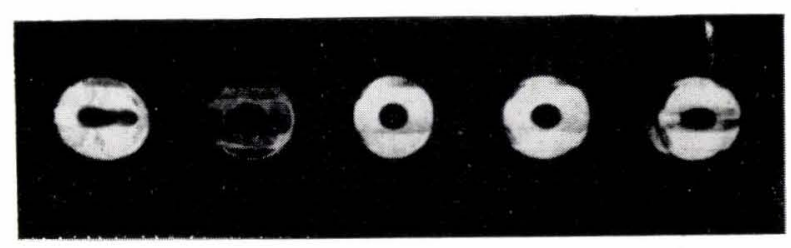

$1 / 2$ KB5750 1/2KB5020 1/2KB5520 1/2KB6520 1/2KB3880

Photo 3. Shapes and dimensions of nozzles

All the original nozzles were replaced by new nozzles $1 / 2 \mathrm{~KB} 6520$, with no appreciable change in surface appearance, as shown in Photo 2(f).

\section{The Sixth Period}

The original main nozzles and the set of five pipes installed in the second period were replaced by a new set of 1/2KB5050 nozzles at a distance of $300 \mathrm{~mm}$ from the roll. The auxiliary nozzles for slow cooling installed in the second period were left unchanged, as illustrated in Fig. 5. The results were a lower roll temperature and improved life of rolls and nozzles.

\section{Discussion}

Table 3. Nozzle test data

\begin{tabular}{|c|c|c|c|c|c|}
\hline Nozzle number & $1 / 2 \mathrm{~KB} 5750$ & $1 / 2 \mathrm{~KB} 5020$ & $1 / 2 \mathrm{~KB} 5520$ & $1 / 2 \mathrm{~KB} 6520$ & 1/2KB3880 \\
\hline Application & Horizontal roll & New product & New product & New product & Vertical roll \\
\hline Spread angle & $50^{\circ}$ & $20^{\circ}$ & $20^{\circ}$ & $20^{\circ}$ & $80^{\circ}$ \\
\hline Flow rate $(l / \mathrm{min})$ at $3 \mathrm{~kg} / \mathrm{cm}^{2}$ & 57 & 50 & 55 & 65 & 38 \\
\hline , $\quad$ at $10 \mathrm{~kg} / \mathrm{cm}^{2}$ & 107 & 94.6 & 103.6 & 123 & - \\
\hline Distance (mm) & 290 & 468 & 468 & 468 & 290 \\
\hline Spraying time (sec) & 8 & 14 & 7 & 5 & 24 \\
\hline Judgment & (Standard) & Poor & Good & Good & - \\
\hline
\end{tabular}




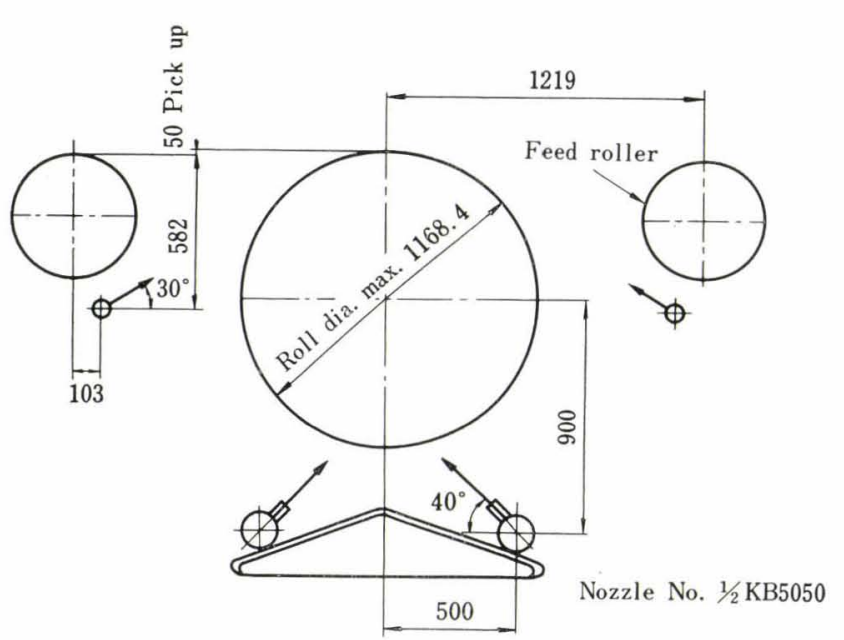

Fig. 5. Roll cooling arrangement in the period VI. (See Photo 2(g))

The surface layers of rolls receive heating and cooling during rolling operation. As the thermal stresses can be shown to exceed the elastic limit of the material, using the temperature values obtained by the measurement described later, the stress-strain hysteresis curve of the material in one rotation encloses a definite area representing an energy loss in a cycle. The damage the roll surface layer receives in rolling can be assessed by the size of that area. It can be shown that the area becomes less when the roll surface is subjected to slow cooling instead of rapid cooling immediately after the delivery of slab. On the other hand, it is definitely advantageous to keep the overall roll temperature as low as possible by, for instance, judicious application of cooling water. Effort was made to meet these apparently conflicting requirement as far as possible, as was described in the foregoing. Considerable improvement was obtained in the roll surfaces, although qualitative, as reflected in the gradual resemblance of the top and the bottom roll surfaces after rolling.

\section{Roll Surface Temperature during Rolling}

Although the temperature to which the roll surfaces are heated during rolling is one of the most important factors influencing the crack behaviour, only few experimental ${ }^{8,12), 13)}$ and theoretical ${ }^{9,10), 11)}$ determinations were made on hot strip or plate mill roll temperature and none on slabbing mill rolls. Thus, temperature measurement using both thermocouple and metallurgical methods was performed on the present mill.

\section{Experimental Procedures}

As the first trial, temperature measurement was made by contacting a chromel-alumel thermocouple against a roll surface at a point close to the delivery point. The temperature record exhibited a considerable fluctuation, presumably because of incomplete contact and heat of friction. Hence, this method was discarded. A metallurgical method was adopted next as an alternative.

Holes of diameter from 4 to $10 \mathrm{~mm}$ by depth from 5 to $10 \mathrm{~mm}$ were drilled in the roll surface, into which quenched steel pieces were fitted. The pieces were of either carbon or alloy steel, whose tempered hardness had been determined previously against various tempering temperatures as exemplified in Fig. 6 for the case of carbon steel. The rolls were set in the mill and used with the quenched pieces embedded.

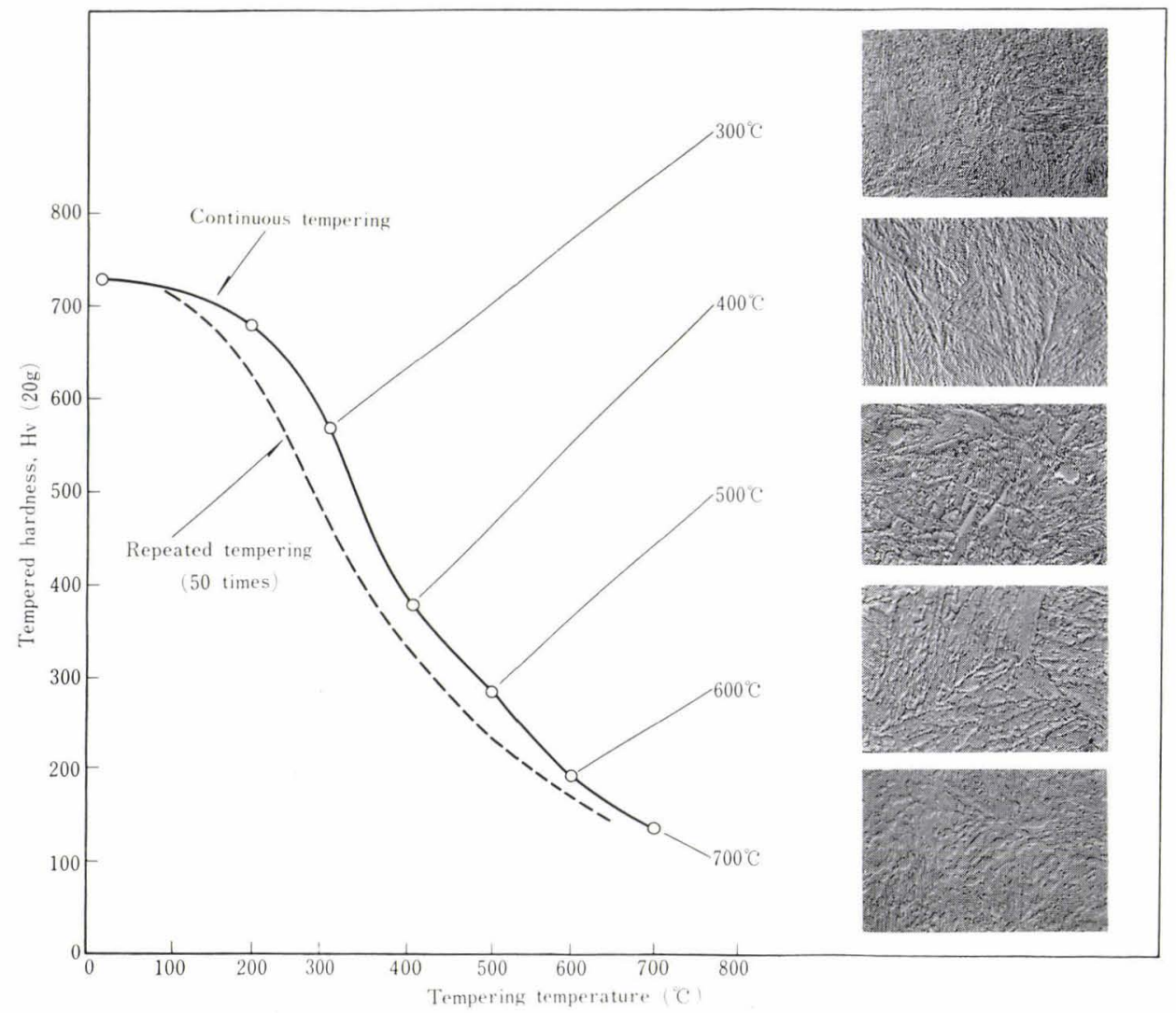

Fig. 6.

Hardness and structure of the steel for plugging $(\times 2,000)$ 
After a certain amount of rolling the rolls were taken out of the mill, the pieces were picked up, sectioned and polished, and their hardness was measured. Estimation of the roll temperature during rolling was made by converting the hardness into the tempering temperature using a graph such as Fig. 6. The total time of contact between the piece and the slabs and the number of repeated heating were also taken into consideration in making the estimation. Electron-microscopic structure was observed and used as reference data. Change of temperature with the depth from the roll surface was estimated from the change of hardness in the piece along its length.

\section{Results}

Fig. 7 is a pair of examples of temperature change along the depth from the roll surface as estimated from the hardness measurement. A close coincidence was noted between temperatures of the top and the bottom rolls, although the latter was slightly higher near the surface than the former. The maximum temperature attained at the surface was approximately $500^{\circ} \mathrm{C}$. A very steep temperature gradient was noted in the layer within $2 \mathrm{~mm}$ from the surface. This was to be expected, because the temperature of slabs was as high as $1,200^{\circ} \mathrm{C}$ and the duration of one contact between slab and a given point on the roll surface was as short as 0.1 second. Severe thermal stress causing fire cracking was probably concentrated in this thin layer.

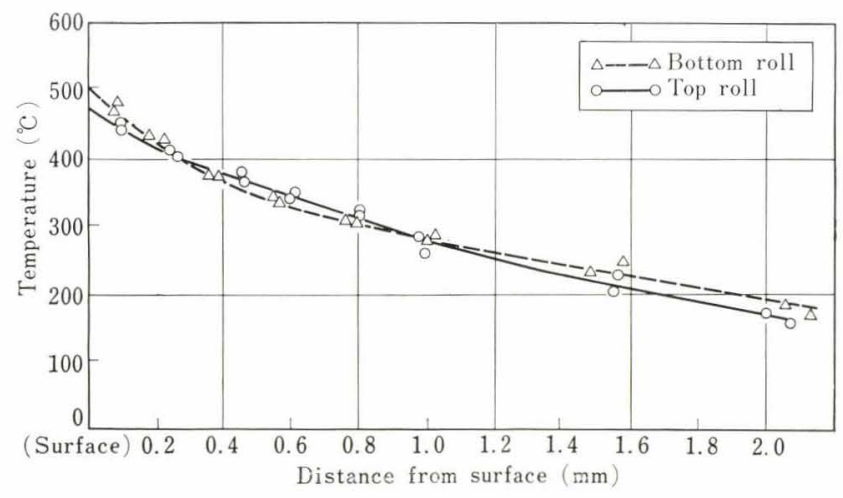

Fig. 7. Temperature distribution in the surface layer of a roll at the middle. (Test No. 4, Period V)

Surface temperatures were determined at different points along the roll barrel length. Maximum temperature was obtained at the middle of the length with values ranging from $470^{\circ}$ to $600^{\circ} \mathrm{C}$. The temperature at points $400 \mathrm{~mm}$ apart from the middle was about $100^{\circ} \mathrm{C}$ lower than the temperature at the middle. A general tendency was observed that the temperatures of the bottom rolls were higher than the top rolls by $20^{\circ}$ to $130^{\circ} \mathrm{C}$.

Measurements were repeated five times as the roll cooling system was changed step by step as was described earlier. The results are summarized in Table 4. It was noted that the temperature difference between the top and the bottom rolls decreased with the change in the cooling system, where the intension of the change was to equalize the situation for the bottom
Table 4. Summarized data of roll surface temperature

\begin{tabular}{|c|c|c|c|c|}
\hline \multirow{2}{*}{$\begin{array}{c}\text { Test } \\
\text { number }\end{array}$} & \multirow{2}{*}{$\begin{array}{l}\text { Plugged-in } \\
\text { material }\end{array}$} & \multirow{2}{*}{ Roll cooling* } & \multicolumn{2}{|c|}{$\begin{array}{l}\text { Roll surface } \\
\text { temperature }\left({ }^{\circ} \mathrm{C}\right)\end{array}$} \\
\hline & & & Top roll & Bottom roll \\
\hline 1 & Cr-Mo steel & Moderate (II) & 535 & - \\
\hline 2 & $\begin{array}{l}\text { Carbon steel } \\
(\mathrm{SK}-3)\end{array}$ & $\begin{array}{l}\text { Strong at the (IV) } \\
\text { middle of roll }\end{array}$ & 470 & 600 \\
\hline 3 & $\begin{array}{l}\text { Carbon steel } \\
(\mathrm{SK}-3)\end{array}$ & $\begin{array}{l}\text { Strong along }(\mathrm{V}) \\
\text { the entire length }\end{array}$ & 510 & 580 \\
\hline 4 & $\begin{array}{l}\text { Carbon steel } \\
(\mathrm{SK}-7)\end{array}$ & (V) & 500 & 520 \\
\hline 5 & $\begin{array}{l}\text { Carbon steel } \\
(\mathrm{SK}-7)\end{array}$ & (VI) & - & 530 \\
\hline
\end{tabular}

roll to that for the top roll.

\section{Effect of Roll Surface Finish on Fire Cracking}

While randomly oriented fire cracks like "tortois shell " may shorten roll life by increasing the amount of dressing, the particular type of cracking observed along the circumference of the bottom roll can be detrimental, as it can lead to roll breakage when combined with the accidental bending force applied to roll during rolling operation. Occurrence of such circumferential cracks was investigated in relation with the method of surface finishing.

\section{Preliminary Laboratory Experiments}

Test pieces of the dimensions of $30 \times 80 \times 20 \mathrm{~mm}$ were subjected to repeated heating and cooling (Fig. 8). Propane flame was used for heating and water for cooling. The temperature of the pieces was controlled by a thermocouple fixed subsurface, and the maximum and minimum were set to $450^{\circ}$ and $50^{\circ} \mathrm{C}$ respectively. After receiving 1,000 thermal cycles, the test pieces were sectioned and the number and depth of cracks were examined.

Three different specimens were prepared with surface finish of $50 \mathrm{~S}$ (depth of irregularity $50 \mu$ ), 20S and as polished. Examination of these specimens after thermal testing revealed no appreciable difference in cracking characteristics among the three, where the lineal average frequency of cracking was about 20 per $\mathrm{cm}$ and the average depth was about $0.2 \mathrm{~mm}$.

In an attempt to see the effect of notches which might be produced accidentally during finish machining, specimens were prepared with four different notches artificially made on the surface separate from each other using a shaper machine. The depth and shape of the notches are listed in Table 5, together with the depth of the cracks observed at the bottom of the notches after thermal testing. All of these notches induced more or less deep cracks under thermal stressing, depending on their shapes. It should be noted that the notches in the earlier experiment were not very different in shape and size from the present ones except that the formers were uniformly distributed over the entire surfaces, whereas the latters were distributed separate from each other. The difference in the cracking behaviour may be attributed to stress 


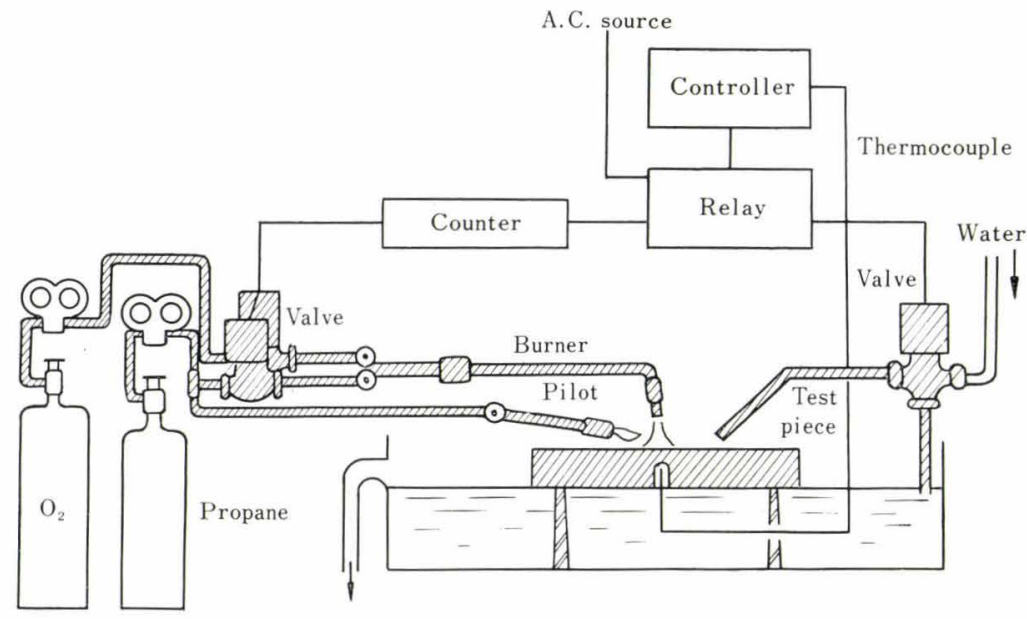

Fig. 8.

Apparatus for fire cracking test
Table 5. Effect of notches on the occurrence of fire cracks

\begin{tabular}{l|c|c|c|c}
\hline Notch depth $(\mathrm{mm})$ & 0.1 & 0.3 & 0.3 & 1.0 \\
\hline Bottom angle & $90^{\circ}$ & $90^{\circ}$ & $90^{\circ}$ & $90^{\circ}$ \\
\hline Bottom shape & Sharp & Sharp & Round & Sharp \\
\hline Range of crack depth & $0.1 \sim 1.1$ & $0.2 \sim 2.2$ & $0.2 \sim 1.1$ & $1.3 \sim 3.1$ \\
\hline $\begin{array}{c}\text { (mm) } \\
\text { Average of crack depth }\end{array}$ & 0.5 & 1.5 & 0.4 & 2.1 \\
\hline $\begin{array}{c}(\mathrm{mm}) \\
\text { Am }\end{array}$ & & & & \\
\hline
\end{tabular}

concentration effect.

\section{Influence of Roll Surface Roughness}

A bottom roll was machined to remove the residual fire cracks completely and divided into 20 sections along the length. Each section was machined with a cutter with radius of $0.75 \mathrm{~mm}$ into one of the three roughness, namely $24 \mathrm{~S}, 59 \mathrm{~S}, 123 \mathrm{~S}$ or ground with grinding machine to the roughness of $5 \mathrm{~S}$. For the case of cutter machining, the following formula was used to obtain the roughness indication.

$$
\mathrm{S}=1,000 f^{2} / 8 r
$$

where $f$ is the feed of the lathe in mm per one rotation and $r$ is the radius of the cutter, $0.75 \mathrm{~mm}$.

The roll was used in the mill and the surface was observed afterwards. As for the randomly oriented "tortois shell" cracks, no difference was found in size and depth of cracks with the difference in finishing. No circumferential cracks were observed within any of the machined sections, except those found at most of the boundaries between differently machined sections, where some kind of step in height could have possibly been present due to the particular machining operation involved. The depth of such circumferential cracks was as deep as $5.5 \mathrm{~mm}$, as proved by redressing the roll, whereas the depth of the randomly oriented cracks was 2 to $3 \mathrm{~mm}$ or less.

\section{Relation to the Feed of Cutter}

In daily operation, other than in the special test described above, flat tipped cutters were used in dressing rolls. The feed of cutter in one revolution was much larger than those used in the above test.

It was observed that many of the circumferential cracks appeared at a regular interval along a roll barrel length. When the feed of cutter was $6.17 \mathrm{~mm}$, the interval of cracking was $6 \pm 1 \mathrm{~mm}$. When the feed was $8.00 \mathrm{~mm}$, the interval was $8 \pm 1 \mathrm{~mm}$, as reproduced in Photo 4. To further ascertain the relationship, a

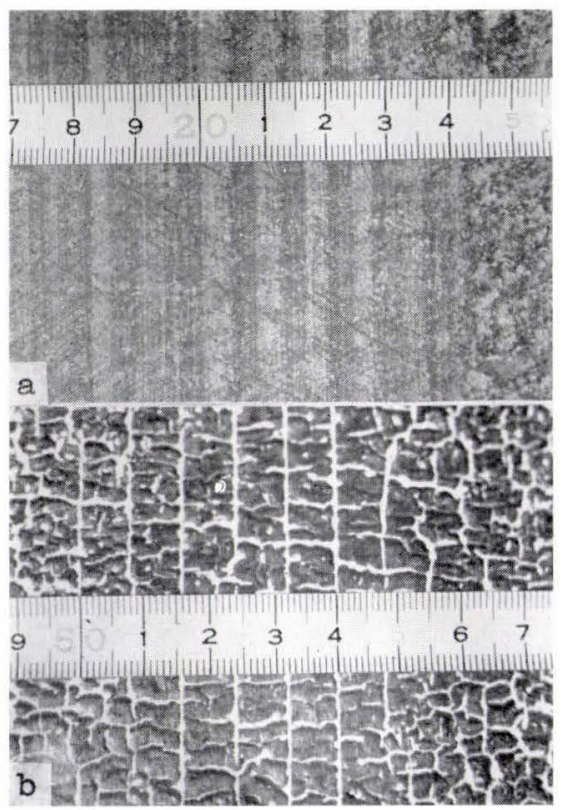

(a) Before rolling (as machined)

(b) After rolling $(\times 0.4)(3 / 5)$

Photo 4. Roll surfaces before and after rolling, showing the relationship between the feed of lathe and the pitch of circumferential cracks

half of the length of a bottom roll was machined with a feed of $4.13 \mathrm{~mm}$ and the other half with $2.11 \mathrm{~mm}$. The intervals of the observed cracks in each half length coincided with each feed of cutter. Thus a close relationship between the texture produced on the surface by machining with a flat-tipped cutter and the occurrence of circumferential cracks was established without doubt, although exact cause for the relation was not clear. The general appearance of the surface prepared by a flat-tipped cutter was quite smooth with no apparent sharp notches, except the regular change of dullness as is seen in Photo 4 (a), corresponding to the feed of cutter. There may be a certain change in material due to the pressure from the cutter, which 
causes the cracks to start.

The above observation leads to the conclusion that one has to be careful not to make separate irregularities on roll surface in machining, since they are most prone to lead to severe cracking, regardless if they have sharp appearance or not.

\section{Roll Wear Relative to Fire Cracking}

A mention should be made here on the relation between roll wear and fire cracking. As apparent in Photo 2, wear of the top roll was much more severe than that of the bottom one. The difference was proved quantitatively as seen in Table 6. Roll diameters were measured with a micrometer before and after using in the mill for a period of one change, the difference was averaged and shown in the table. It can be seen that the top rolls worn $35 \%$ more than the bottom. This difference is clearly to be attributed to the conditions under which the both rolls were used, not to the difference in the material of the rolls, because each roll was set in the top and bottom position in turn.

Surface temperature could not be responsible for the difference in wear, for the temperature of the top rolls was lower than the bottom as was described in the foregoing section. There was found a difference in the revolving speeds of the both rolls, as will be described in the later section, and this was considered to be the major factor influencing the wear difference. It should be noted that the top rolls, that exhibited more wear than the bottom, suffered less fire cracking, on the other hand.

When examining a single roll, difference in the amount of wear was observed along the roll barrel length. In case of top rolls, the maximum wear was observed at the middle of the length, gradually decreasing towards the both ends, thus forming a $\mathrm{V}$ type profile. In bottom rolls, W type profile was consistently observed, where the maximum wear was obtained at points 300 to $500 \mathrm{~mm}$ apart from the middle towards the both ends. Appearance of fire cracking was examined relative to the wear of bottom rolls and it was found that location of the largest unit crack cells coincided with the location of maximum wear, namely the two valleys of the $\mathrm{W}$ profile.

From the above observation, it may be said that, although the amount of wear should preferably be minimized with regard to roll life, wear also suppresses severe development of fire cracking, and thus a limited amount of wear may be allowed as a necessary evil. A probable solution for this problem may be to try to equalize the amount of wear and the degree of cracking in both the top and bottom rolls.

\section{Analysis of Roll Speed}

Revolving speeds of both top and bottom rolls were recorded by means of movie camera and analized in relation to the amount of wear in the both rolls, which in turn was considered to be related to fire cracking behaviour.

The mill was of twin motor drive type, and so there was a possibility that the speeds of the both rolls were not the same, although the mill was equipped with an automatic load balancing mechanism.

\section{Experimental Procedures}

Although the mill was equipped with a standard type electronic revolution recorder, its indication was
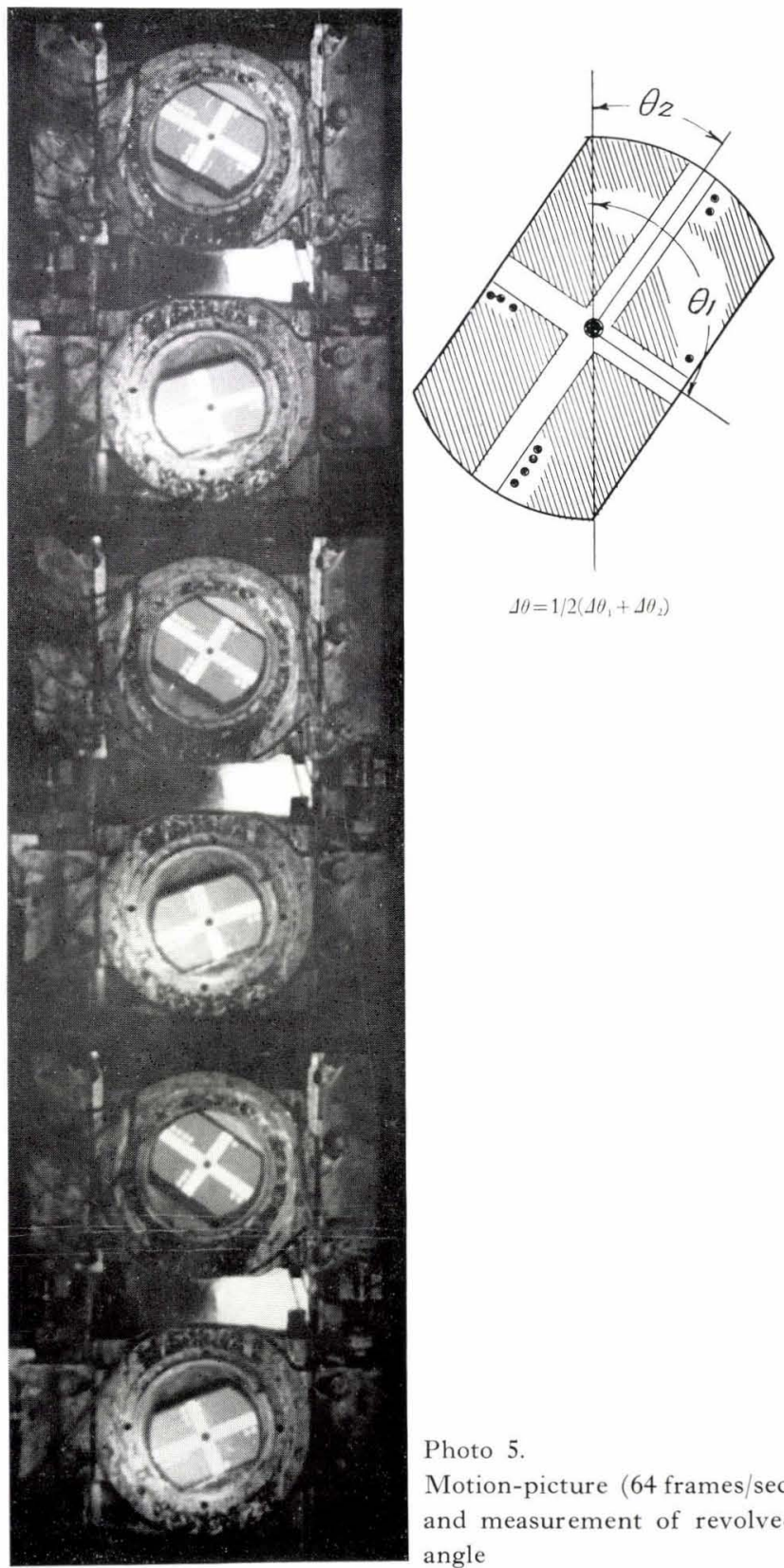

$\Delta \theta=1 / 2\left(\Delta \theta_{1}+\Delta \theta_{2}\right)$

Photo 5 .

Motion-picture (64 frames/sec) and measurement of revolved angle

Table 6. Roll wear data

\begin{tabular}{|c|c|c|c|c|c|c|c|c|c|}
\hline \multirow{2}{*}{$\begin{array}{l}\text { Number } \\
\text { of roll } \\
\text { changes }\end{array}$} & \multirow{2}{*}{$\begin{array}{l}\text { Number } \\
\text { of } \\
\text { rolls used }\end{array}$} & \multirow{2}{*}{$\begin{array}{l}\text { Total of } \\
\text { rolled weight } \\
(t)\end{array}$} & \multicolumn{3}{|c|}{ Wear of top roll (mm) } & \multicolumn{3}{|c|}{ Wear of bottom roll } & \multirow{2}{*}{$\begin{array}{c}\text { Wear ratio } \\
\frac{\text { (Top roll) }}{\text { (Bottom roll) }}\end{array}$} \\
\hline & & & Total & $\begin{array}{l}\text { Per one } \\
\text { change }\end{array}$ & Per $1,000 t$ & Total & $\begin{array}{l}\text { Per one } \\
\text { change }\end{array}$ & Per $1,000 t$ & \\
\hline
\end{tabular}


considered not sufficiently precise as a basis for discussing the difference of revolving speeds of the both rolls. Hence, movie camera was adopted.

A cross was painted as a marker on the end of the worker's side axis of each roll and a motion picture was taken of the both rolls at the same time with 16 $\mathrm{mm}$ movie camera at a speed of 64 frames per second. A cut from the film is reproduced in Photo 5. By measuring the revolved angles of the crosses, the speed of revolution was determined with a precision sufficient for the present purpose. In particular, exact determination of the relative speed of the rolls to each other was made possible by this arrangement. The recording was made when rolling a 12-ton ingot, which was rolled in 15 passes into a $175 \mathrm{~mm}$ thick slab. Both rolls were of the same diameter, namely $1,165 \mathrm{~mm}$.

\section{Results}

In Fig. 9 roll speeds in No. 9 and 10 passes are plotted against time from the start of each pass. A slight difference in speed of top and bottom rolls can be seen, although not quite clear in this plotting fashion. In No. 10 pass the rate of increase of roll speed is higher than in No. 9 pass. This was because the vertical rolls were located opposite side from the soaking pit, and hence in case of an even number pass, a slab was accelerated by the vertical rolls before entering the horizontal rolls.

In Fig. 10 the difference of the revolved angles between the top and bottom rolls (top minus bottom) was plotted against time from the start of each pass. It is clearly seen that the top roll revolved more than the bottom. In this figure two odd number passes and two even number passes are shown. The difference of angles is larger in the even number passes than in the odd number passes, presumably because the rate of increase of speed immediately after start was higher in the former.

During the actual rolling period, i.e. from entry to delivery, there is a tendency for the curves to flatten, indicating that the speeds of the both rolls are approaching to each other. This happened most probably by the work of the load balancing mechanism of the mill. However, in case of even number passes,
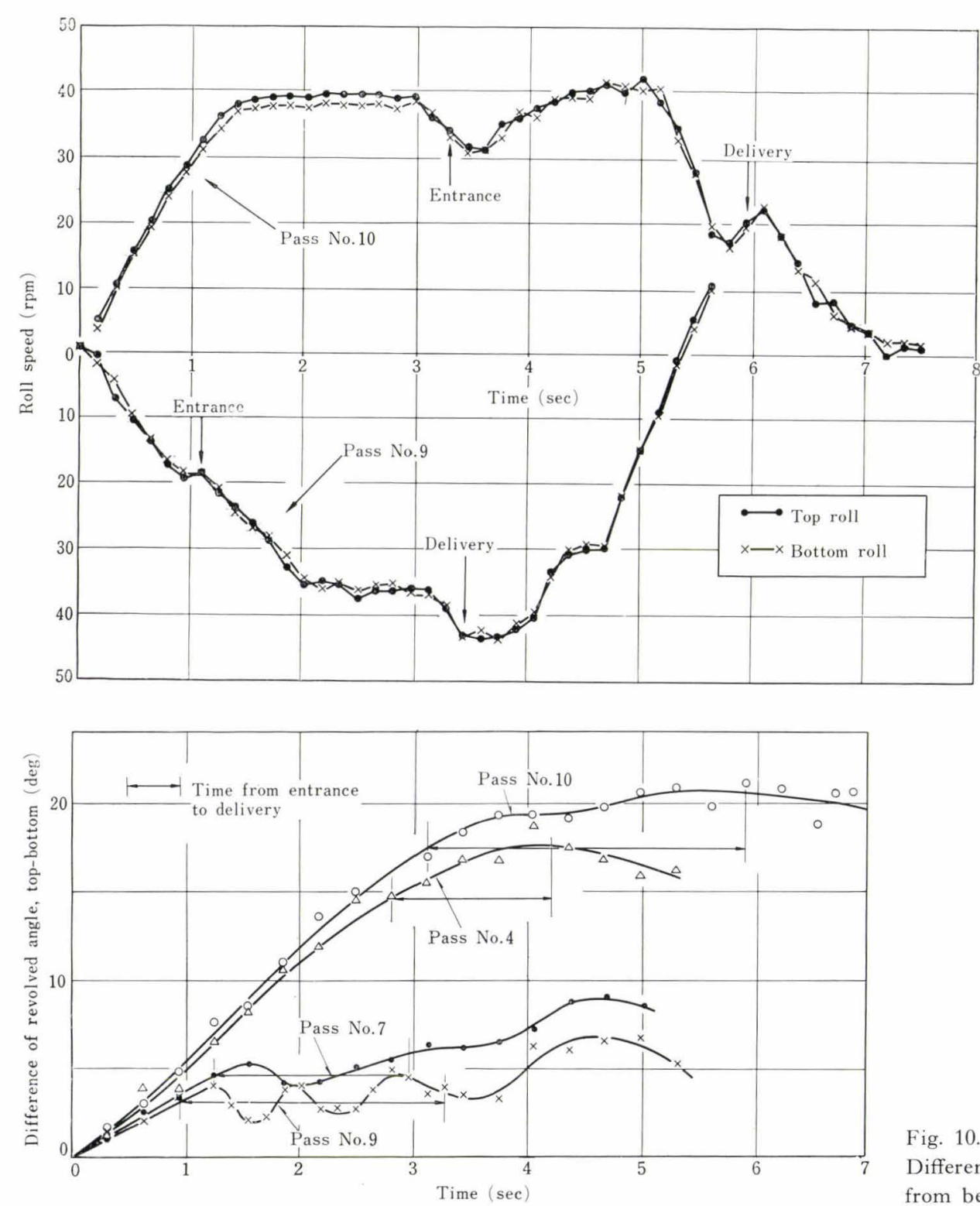

Fig. 9.

Roll speed on Nos. 9 and 10 passes
Fig. 10.

Difference of revolved angle (top-bottom) from beginning of pass 
there still exists a difference in speeds even at the point of delivery. In case of odd number passes, the balancing action is clearly in better action, but the action is apparently in a transient state and has not been stabilized up to the point of delivery.

When averaged, the top roll revolved 2 degree more than the bottom during the actual rolling in a pass, totalling to 30 degrees for the 15 passes for one slab. It can safely be said that the effect of the load balancing mechanism of this mill is not perfect.

This excess revolution of the top roll was unlikely to have been used for actual deformation of slabs, as no downward deflection of slab was observed. Thus, it is probable that the top roll simply slipped on slabs, and this caused the greater wear of the roll.

The roll speed charts recorded by the standard recorder of the mill were compared to the motion picture data, and it was confirmed that the response of the recorder was not quick enough to follow the actual roll speed.

\section{Conclusions}

The following is the summary of the present investigation on fire cracking and related variables in the horizontal rolls of a slabbing mill.

(1) Cooling system for the top roll was found to be more effective in minimizing fire cracking than that for the bottom roll. Effort was made to simulate the condition of cooling for the bottom roll to that of the top roll. Location of the spray on the roll was changed so as to cool the roll slowly immediately after delivery. Type of spray nozzles was carefully chosen so as to maintain sufficient cooling.

(2) Temperature in the surface layer of rolls during rolling was estimated from the change of hardness of the quenched steel pieces embedded in the roll surface. The maximum temperature near the surface was approximately $500^{\circ} \mathrm{C}$. Heating was concentrated essentially within $2 \mathrm{~mm}$ from the surface. Bottom roll temperature was somewhat higher than the top roll.
Maximum temperature was obtained at the middle of the roll barrel length. These differences were greatly smoothed out by improving the roll cooling system.

(3) The nature of machined surface was found highly critical to the occurrence of circumferential cracks, which might possibly lead to eventual roll breakage. Even apparently smooth surface provided by a flat-tipped cutter could lead to such cracks.

(4) Amount of wear was related to fire cracking. The top rolls wore down with a V type profile. $35 \%$ more wear was found on the top rolls than the bottom rolls, and little cracking was observed on the former. The bottom rolls wore down with a W type profile, and less severe cracking was observed at location where wear was greater.

(5) Analysis of motion picture revealed that the top roll revolved about $1 \%$ faster than the bottom. This was considered, at least, partly, responsible for the greater wear of the top roll.

Assisted by those findings, effort of both the roll makers and the user was accumulated to a point where the roll performance was doubled compared to that at the beginning of the present project.

\section{REFERENCES}

1) C. Utahashi et ali.: Tetsu-to-Hagané, 51 (1965), 1, 39-59.

2) C. Utahashi et ali. : ibid., 49 (1963), 10, 1617-1624.

3) J. Watanabe: ibid., 47 (1961), 925-929.

4) T. Okumoto et ali. : ibid., 50 (1964), 4, 598-601.

5) N. R. Arant: Iron \& Steel Eng., 36 (1959), 11, 100-107.

6) W. Hesse: Stahl u. Eisen, 77 (1957), 715-727.

7) M. Hachisu: Hitachi-Hyoron, Spec. Issue, 33 (1959), 50-57.

8) A. M. Belansky et ali.: Iron \& Steel Eng., 33 (1956), 3, 62-64.

9) C. F. Peck et ali. : ibid., 31 (1954), 6, 45-58.

10) C. F. Peck et ali.: ibid., 32 (1955), 8, 121-130.

11) Y. Sekimoto: Hitachi-Hyoron, Spec. Issue, 42 (1961), 43-49.

12) W.J. Williams: Iron Eै Steel, 35 (1962), 8, 372-383.

13) M. A. Tylkin et ali. : Stal, 10 (1964), 802(906)-805(909).

14) E. Niiyama et ali.: Hitachi-Hyoron, Spec. Issue, $(1964,11)$ $122-126$. 